\title{
ŚWIATOWE DNI MŁODZIEŻY 2016 - ANALIZA ZAGROŻEŃ I SZACOWANIE RYZYK KOMUNIKACYJNYCH. STUDIUM NA PRZYKŁADZIE DNI DIECEZJALNYCH W WOJEWÓDZTWIE PODKARPACKIM
}

\begin{abstract}
Światowe Dni Młodzieży to czas, kiedy młodzi ludzie, katolicy,choćnie tylko, z całego świata przyjeżdżają na spotkanie z Ojcem Świętym i innymi podobnymi im ludźmi. Spędzają czas na modlitwach, czuwaniach, rozmowach i poznawaniu często nowego dla nich miejsca. To niewątpliwie okazja, żeby przeżyć niepowtarzalną przygodę w bliskości ludzi patrzących na świat podobnie i podobnie postrzegających jego wartości. Ze względu na rozmiar imprezy i skalę działań, jakie muszą być podejmowane dla sprawnego jej przeprowadzenia, konieczne jest, żeby dokładnie przeanalizować zagadnienia dotyczące bezpieczeństwa. Impreza sama w sobie nie jest ani sytuacją kryzysową, ani masową imprezą podwyższonego ryzyka. Niemniej jednak, zwłaszcza w obliczu zagrożeń terrorystycznych materializowanych w krajach tak zwanej „starej Europy” potrzebne są działania analityczne i oparte na ich wynikach działania operacyjne, które pozwolą przygotować imprezę i całe jej otoczenie w sposób zapewniający bezpieczeństwo dla wszystkich uczestników, niezależnie od tego, skąd na nią przyjadą. Program imprezy zakłada dwie części. Pierwsza, etap diecezjalny, zaplanowany od 20 do 25 lipca 2016 r., odbywać się będzie w rozsianych po kraju parafiach, gdzie goście z całego świata wezmą udział w programach przygotowanych przez lokalne społeczności. Druga, zasadnicza część imprezy zacznie się 25 i potrwa do 31 lipca 2016 r. Będzie to czas spotkania pielgrzymów z Ojcem Świętym i wspólnej z nim modlitwy. Należy oczekiwać, że cała populacja uczestników zechce wtedy dotrzeć do Krakowa i jego najbliższych okolic. Oznacza to, że niespełna 800-tysięczne miasto będzie gościć rzeszę pielgrzymów szacowaną nawet na 3 miliony osób.
\end{abstract}

Słowa kluczowe: ŚDM, komunikacja, zagrożenie, ryzyko.

\section{WPROWADZENIE}

Zaplanowane na ostatnią dekadę lipca 2016 roku Światowe Dni Młodzieży (ŚDM) w Polsce będą imprezą bez precedensu. Wprawdzie za pontyfikatu papieża Jana Pawła II wiele miast i miejscowości w naszym kraju gościło Ojca Świętego, to nigdy wcześniej nie wiązało się to z tak licznym udziałem osób spoza Polski - pielgrzymów z całego świata. Szacowana liczba uczestników oscyluje pomiędzy 2 a 3 milionami osób. W chwili pisania tego artykułu autor nie był w stanie jednoznacznie oszacować, której z wcześniej wymienionych granic bliższa będzie ostateczna liczba gości. Słowo „gość” jest tu odpowiednie zewzględuna to, że rejestracja nie jest obowiązkowa, a na spotkanie z Ojcem Świętym przyjść może każdy. Oznacza to, że wszelkie oszacowania stoją pod wielkim znakiem zapytania zarówno co do skali, jak i narodowości uczestników.

${ }^{1}$ Dr Stanisław J. Rysz, Podkarpacki Urząd Wojewódzki w Rzeszowie, Wydział Bezpieczeństwa i Zarządzania Kryzysowego, ul. Grunwaldzka 15,35-959 Rzeszów, tel.: 1786717 11, e-mail: stanislaw.rysz@vp.pl 
Wprawdzie impreza sama w sobie nie stanowi ani sytuacji kryzysowej w myśl ustawy z dnia 26 kwietnia 2007 r. o zarządzaniu kryzysowym², ani nie jest imprezą masową, a tym bardziej imprezą masową podwyższonego ryzyka $\mathrm{w}$ rozumieniu ustawy $\mathrm{z}$ dnia 20 marca 2009 r. o bezpieczeństwie imprez masowych ${ }^{3}$, to jednak z powoduswojej skali, liczby uczestników, okoliczności towarzyszących i sposobu zorganizowania wymaga się, żeby w celuoptymalizacji jej przebiegu do analiz, planów, programów, procedur i w konsekwencji - do jej zrealizowania wykorzystać zasoby i doświadczenia zebrane w ramach realizacji procedur zarządzania kryzysowego.

Światowe Dni Młodzieży będą okazją do modlitw, spotkań z papieżem, wzajemnego poznawania się Polaków i obcokrajowców, zwiedzenia Polski, jej atrakcji krajobrazowych, kulturowych, historycznych i architektonicznych. Impreza została zaplanowana w dwóch etapach. Pierwszy, w dniach od 20 do 25 lipca, to pobyt gości w polskich parafiach - „dni diecezjalne”. Przyjezdni będą mieszkać wśród miejscowych, uczestniczyć w ich codziennym życiu, zwiedzać okolicę i doświadczać miejscowej kultury. Na tym etapie, niejako poprzedzającym i przygotowującym do udziału w zasadniczych ŚDMw Krakowie, wielkość liczby obcokrajowców nawiązuje do deklaracji poszczególnych biskupów diecezjalnych ${ }^{4}$. W diecezjach, które przygotowują się do podjęcia zagranicznych gości, ŚDM działają specjalnie na ten cel zorganizowane centra, w których odbywa się teleinformatyczna rejestracja chętnych. Odpowiedzialność za pobyt gości będzie w tym czasie spoczywać na organizatorach w diecezji.

Ponieważ granice diecezji nie pokrywają się z podziałem administracyjnym Polski, w wielu wypadkach konieczna będzie współpraca przedstawicieli strony kościelnej $\mathrm{z}$ poszczególnych diecezji z organami samorządowymi i rządowymi ${ }^{5}$ z różnych powiatów i województw. Ze względu na charakter imprezy i program zaplanowany do zrealizowania w jej trakcie w celuzapewnienia optymalnego przebiegu należy dokonać analizy potencjalnych zagrożeń i oszacowania ryzyk, jakie się z nimi wiążą.

Zagrożenie $^{6}$ oznacza zjawisko naturalne lub będące efektem myśli i woli ludzkiej, które ma potencjał do wywarcia, w wypadku zaistnienia sprzyjających warunków, istotnych negatywnych skutków, szkód i strat w którejkolwiek spośród domen: populacja, zasoby lub środowisko naturalne. Samo w sobie zagrożenie nie generuje szkód ani strat. Te ostatnie są skutkiem zmaterializowania się zagrożenia.

Prawdopodobieństwo ${ }^{7}$ (p) materializacji zagrożenia oznacza matematyczne wyrażenie szansy zaistnienia rozważanego zdarzenia i mieści się w obustronnie zamkniętym przedziale od zera do jedności $(p \in<0 ; 1>)^{8}$. W niniejszym opracowaniu prawdopodobieństwo będzie rozpatrywane $\mathrm{w}$ trybie szacunkowym i wyrażane $\mathrm{w}$ pięciostopniowej skali.

2 Dz.U. 2007 nr 89 poz. 590.

${ }^{3}$ Dz.U. 2009 nr 62 poz. 504.

${ }^{4}$ Rzeczywista liczba gości w poszczególnych diecezjach będzie znana dopiero w chwili, kiedy pojawią się oni w docelowych parafiach.

${ }^{5}$ Dla przykładu w województwie podkarpackim jest 5 diecezji rzymsko-katolickich, 1 diecezja greko-katolicka, z których tylko 1 (archidiecezja przemyska) w całości znajduje się na obszarze administracyjnym województwa podkarpackiego. Pozostałe, w mniejszej lub większej części, przynależą terytorialnie do innych województw.

${ }^{6}$ Opracowanie własne autora.

${ }^{7}$ Wśród określeń synonimicznych dla słowa „prawdopodobieństwo” używa się także określeń „częstość”, „,częstotliwość”.

${ }^{8}$ Prawdopodobieństwo wynosi 0 dla zdarzeń niemożliwych do materializacji, a 1 dla zdarzeń pewnych. Wszystkie liczby pomiędzy 0 a 1 wyrażają szansę zrealizowania. 
Skutkiem materializacji zagrożenia jest wystąpienie szkód. Pod pojęciem szkody rozumie się negatywne skutki materializacji zagrożenia. Do analiz wykorzystuje się pojęcie strat (S), które ujmuje w wymiarze finansowym szkody powstałe w wyniku materializacji zagrożenia. Do szacowania strat wykorzystywane będzie podejście udziałowe strat powstałych $\mathrm{w}$ wyniku materializacji zagrożenia do całkowitej wartości uszkodzonych zasobów ${ }^{9}$. Podobnie jak w wypadku prawdopodobieństwa, także $\mathrm{w}$ odniesieniu do strat wynikłych $\mathrm{z}$ materializacji zagrożenia zastosowano podejście szacunkowe oraz sposób wyrażania przy użyciu pięciostopniowej skali.

Przez określenie ryzyko ${ }^{10}$ rozumie się iloczyn matematyczny (lub logiczny) prawdopodobieństwa wystąpienia materializacji określonego zagrożenia oraz wymiernej wielkości skutków (strat) (rys. 1).

Rys.1. Ryzyko materializacji zagrożenia -iloczyn prawdopodobieństwa i strat

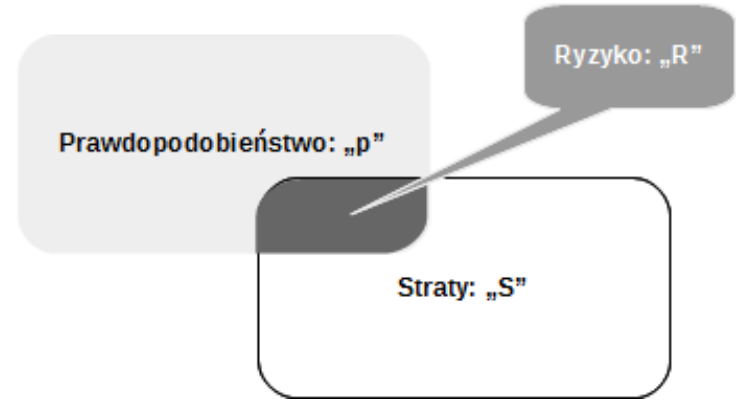

Źródło: opracowanie własne autora ${ }^{11}$.

Zewzględuna przyjęty do rozważań etap można założyć, że liczba uczestników imprez organizowanych w ramach dni diecezjalnych może stanowić około podwójnej liczby zagranicznych gości. Oszacowanie zakłada, że statystyczna polska rodzina ${ }^{12}$ (dwoje rodziców i dwoje dzieci) będzie gościć dwie osoby. Jako gospodarze i aktywni uczestnicy inicjatyw parafialnych z dużym prawdopodobieństwem będą towarzyszyć swoim gościom $\mathrm{w}$ imprezach plenerowych, estradowych i religijnych, jakie będą organizowane. Nawet jeśli z różnych przyczyn nie wszyscy jednocześnie, to pojedynczo, w dwie lub trzy osoby będą towarzyszyć swoim gościom w realizacji programu pobytu. W zależności od diecezji oznacza to liczby od 5 tysięcy do 30 tysięcy osób. Tego założenia nie można uogólnić na wyjazdy turystyczne. Te ostatnie będą odbywane przede wszystkim w gronie samych zagranicznych grup lub tylko $\mathrm{z}$ udziałem kilkorga porozumiewających się $\mathrm{w}$ obcych językach parafian.

Pewne zagrożenie wiąże się także z porą roku i związanymi z nią charakterystycznymi cechami klimatu. Lipiec to w Polsce miesiąc, kiedy występują najwyższe temperatury

\footnotetext{
${ }^{9}$ Straty $\mathrm{S}=0$, jeśli materializacja nie spowodowała żadnych strat $\mathrm{w}$ rozpatrywanych zasobach, $\mathrm{S}=1$ zaś, jeśli zasoby zostały całkowicie zniszczone.

${ }^{10}$ Innym określeniem ryzyka jest szansa.

${ }^{11}$ Wszystkie użyte w opracowaniu rysunki i tabele są opracowaniami własnymi autora.

${ }^{12} \mathrm{P}$. Ulman w artykule Polskarodzina w świetle wybranych badań statystycznych szacuje, że statystyczna polska rodzina składa się średnio z 2,82 osoby, z czego w mieście to 2,54 osoby, a na wsi 3,40. „Studia SocialiaCracoviensia” 10/6 (2014), s. 153-167.
} 
oraz największe opady ${ }^{13}$. Dodatkowym czynnikiem powodującym zagrożenia jest to, że są to $\mathrm{w}$ dużej mierze opady związane $\mathrm{z}$ burzami. To oznacza, że nie można w analizach pominąć zagrożeń związanych ze zjawiskami pogodowymi i hydrologicznymi ${ }^{14}$. Z kolei w obliczu długotrwałego pozostawania w nasłonecznionych miejscach możliwe są zdrowotne problemy wśród uczestników imprez towarzyszących. Może to wymagać pomocy ze strony wyspecjalizowanych służb i systemów ${ }^{15}$. Trzeba także zauważyć, że wielu spośród gości po raz pierwszy spotka się z polską kuchnią i potrawami. Skutkiem tego może być niestrawność, a nawet zatrucie pokarmowe, które także stanowią zagrożenia dla właściwego przebiegu wizyt. Na podstawie doświadczeń wyniesionych z podobnych analiz podejmowanych $\mathrm{w}$ związku $\mathrm{z}$ innymi okolicznościami autor sugeruje potencjalne zagrożenia związane $\mathrm{z}$ następującymi zdarzeniami:

1) awarie autobusów;

2) awarie pociągów;

3) wypadki komunikacyjne $z$ udziałem autobusów;

4) wypadki komunikacyjne $z$ udziałem pociągów;

5) wypadki komunikacyjne $z$ udziałem samolotów;

6) problemy logistyczne w obsłudze transportów;

7) przerwyw dostawach energii elektrycznej do trakcji kolejowej;

8) terroryzm;

9) zbiorowezachorowania lub zatrucia;

10) epidemie;

11) epizootie;

12) problemy kwaterunkowe;

13) zjawiska pogodowe i hydrologiczne;

14) problemyz dostawą energii elektrycznej;

15) problemyz dostawąwody;

16) pożary wielkoobszarowe;

17) nagły napływ dużej liczby imigrantów;

18) kradzieże i wymuszenia;

19) niepokoje społeczne;

20) lęki paniczne;

21) problemy wizerunkowe.

Ze względu na ograniczony rozmiar niniejszego opracowania autor skupi się w nim nad wybranymi $\mathrm{z}$ tejlisty zagadnieniami związanymi $\mathrm{z}$ komunikacją zbiorową ${ }^{16}$. W dalszej części opracowania przeprowadzono rozważania odnośnie do każdego ze wskazanych zagrożeń, prawdopodobieństw ich materializacji i oszacowań skutków, jakie taka materializacja mogłaby spowodować. W celuujednolicenia treści artykułu do analiz i oszacowań autor wykorzystał metodę opisową w odniesieniu do wszystkich rozważanych zagrożeń. Prawdopodobieństwo materializacji oraz szacowany rozmiar szkód rozważano

\footnotetext{
${ }^{13}$ Na przestrzeni lat 1981-2010 w Rzeszowie średnia dobowa temperatura powietrza w lipcu była najwyższa wśród miesięcy i wynosiła $18,8^{\circ} \mathrm{C}$. Podobnie średnia wielkość sumy opadów w lipcu była najwięeksza i wynosiła 90,7 mm (blisko 100 litrów na metr kwadratowy). Opracowanie własne autora na podstawie danych ze strony: http://www.pogodynka.pl/polska/daneklimatyczne (dostęp: 29.01.2016).

${ }^{14}$ Niezależnie od odbywanych imprez w naturze mogą zdarzyć się burze, wichury, wiatrołomy, powodzie, osuwiska i inne sytuacje kryzysowe.

${ }^{15}$ Tu: System Państwowe Ratownictwo Medyczne.

${ }^{16}$ Pozycje 1-8 na przedstawionej liście rozpatrywanych zagrożeń.
} 
według pięciostopniowej skali, jak w tabeli $1^{17}$. Po przeanalizowaniu listy zagrożeń związanych z organizacją i przeprowadzaniem transportów zbiorowych (autobusowych, kolejowych oraz lotniczych) przeprowadzono ocenę ryzyka przy użyciu matrycy strategicznej. Ze względu na charakter strat, jakie mogą zaistnieć na skutek zmaterializowania przedmiotowych zagrożeń,założono, że wszelkie ryzyka dla strat zupełnych oraz prawdopodobieństw większych niż minimalne traktowano jako nieakceptowalne.

Tabela 1. Skale opisowe do szacowania prawdopodobieństwa materializacji zagrożenia oraz szkód, jakie to może powodować.

\begin{tabular}{|c|c|c|}
\hline Oznaczenie: & $\begin{array}{c}\text { Opis prawdopodobieństwa } \\
\text { (częstości) zdarzenia }\end{array}$ & $\begin{array}{c}\text { Opis ciężkość następstw } \\
\text { (strat) }\end{array}$ \\
\hline 1 -minimalne & $\begin{array}{l}\text { Zdarzenie występuje wyjątkowo rzadko: } \\
\text { raz na kilka lat albo rzadziej }\end{array}$ & $\begin{array}{l}\text { Szkody są minimalne i przekładają się na } \\
\text { niewielkie straty, powodują niewielkie } \\
\text { koszty ich usuwania albo naprawy, nie } \\
\text { powodują zagrożenia dla zdrowia i życia } \\
\text { poszkodowanych }\end{array}$ \\
\hline 2 - małe & $\begin{array}{l}\text { Zdarzenie występuje bardzo rzadko: raz na } \\
\text { rok albo raz na } 2-3 \text { lata }\end{array}$ & $\begin{array}{l}\text { Szkody są dostrzegalne i mają przełożenie } \\
\text { na straty, które można pokryć bez } \\
\text { istotnego uszczerbku w budżecie }\end{array}$ \\
\hline 3 -średnie & $\begin{array}{l}\text { Zdarzenie występuje średnio często: raz na } \\
\text { kilka miesięcy albo raz na rok }\end{array}$ & $\begin{array}{l}\text { Szkody są istotne i dokuczliwe, a straty są } \\
\text { odczuwalne w budżecie, mogą powodować } \\
\text { zmęczenie i zranienia u poszkodowanych }\end{array}$ \\
\hline 4 -duże & $\begin{array}{l}\text { Zdarzenie występuje często: raz na kilka } \\
\text { tygodni albo raz na kilka miesięcy }\end{array}$ & $\begin{array}{l}\text { Szkody są spore, a na ich usuwanie } \\
\text { potrzeba specjalnie odłożyć lub pozyskać } \\
\text { pieniądze, zagrażają zdrowiu } \\
\text { poszkodowanych }\end{array}$ \\
\hline 5 - zupełne & $\begin{array}{l}\text { Zdarzenie występuje bardzo często: raz na } \\
\text { kilka dni albo raz na kilka tygodni }\end{array}$ & $\begin{array}{l}\text { Szkody są bardzo duże, zniszczeniu } \\
\text { ulegają wykorzystywane urządzenia oraz } \\
\text { inne przedmioty, które znajdują się w } \\
\text { pobliżu miejsca zdarzenia,uszkodzenia } \\
\text { dotyczą również budynku (obiektu), w (na) } \\
\text { którym doszło do zdarzenia,poszkodowani } \\
\text { doznają urazów i muszą być pod opieką } \\
\text { medyczną,występuje zagrożenie ich } \\
\text { życia,mogą pojawić się ofiary śmiertelne }\end{array}$ \\
\hline
\end{tabular}

\section{ANALIZA ZAGROŻEŃ I SZACOWANIE RYZYK}

Ze względu na złożoność materii spraw autor do rozważań przyjął zagadnienie zbiorowych transportów realizowanych na potrzeby przemieszczania się grup uczestników ŚDM pomiędzy punktami zbiórek a miejscami docelowymi.

\subsection{Awarie środków transportu}

\subsubsection{Autobusy}

Ze względu na swoją mobilność autobusy ${ }^{18}$ są najczęściej używanym środkiem transportu dla grup zorganizowanych. Mając na względzie fakt, że w ciąguzaledwie kilku dni potrzebne będzie użycie bardzo wielu środków transportu, należy oczekiwać, że do

\footnotetext{
${ }^{17}$ Przedstawiona tabela jest efektem przemyśleń autora w nawiązaniu do podobnych opracowań zawartych w literaturze przedmiotu.

${ }^{18}$ Pod określeniem ,,autobus” rozpatrywane będą także mniejsze pojazdy określane mianem „bus”.
} 
realizacji usługi zostaną wykorzystane autobusy w różnym stanie technicznym. Oprócz pojazdów nowych pojawią się także autobusy starsze. Oczywiście wyruszając w trasę, wszystkie będą posiadać wymagane badania techniczne, ale zewzględuna wiek i przebieg ich możliwości trakcyjne będą obarczone odczuwalnymi limitami. Kulminacja, szczególnie duże zapotrzebowanie na autobusy do transportu uczestników, wystąpi 25 lipca, kiedy wszyscy chętni na spotkanie z papieżem będą się przemieszczać do Krakowa i w jego najbliższe okolice. Niektóre grupy, zwłaszcza te, które przybędą z zachodnich krajów europejskich, będą się poruszać własnymi pojazdami, których stan techniczny nie powinien wzbudzać większych zastrzeżeń. Największe problemy mogą sprawiać pojazdy przybywające przez naszą wschodnią granicę oraz samochody zarejestrowane w Polsce, wyeksploatowane, ale tanie w wynajmie ${ }^{19}$.Zakłada się, że uszkodzeniu mogą ulegać przede wszystkim koła, układy klimatyzacji i wentylacji kabiny, układy chłodzenia silnika i inne, podobne podzespoły, które zazwyczaj nie generują katastrof w ruchu drogowym. W tabeli 2 zebrano oszacowane wartości odnośnie do materializacji zagrożenia: prawdopodobieństwo „średnie” $(\mathrm{p}=3)$ oraz szkody „małe” $(\mathrm{S}=2)$. Takie oszacowanie prawdopodobieństwa autor przyjął zewzględuna wysoką temperaturę powietrza oraz możliwe duże przebiegi autobusów. Zasadnejest przyjęcie hipotezy, że mocno zużyte pojazdy o dużym przebiegu mogą mieć raz na kilka miesięcy problemy eksploatacyjne. Oszacowanie strat na poziomie „małe” $(S=2)$ to efekt założenia, że awaria może wprawdzie spowodować niewielkie straty materialne, które dotkną świadczącego usługę transportową. Ich koszt będzie do pokrycia na podstawie dostępnych na bieżąco zasobów bez istotnego zaburzenia płynności finansowej poszkodowanego podmiotu. Osobnym zagadnieniem będą w takich wypadkach straty wizerunkowe związane z zamieszaniem i negatywnymi emocjami wśród podróżnych. W zależności od rodzaju uszkodzenia ${ }^{20} \mathrm{~W}$ grę wchodzą dwa warianty: zmiana pojazdu na inny - sprawny, albo naprawa uszkodzonego. Niezależnie od wyboru opcji, za każdym razem wystąpi jakieś, mniejsze lub większe, opóźnienie w podróży, które może spowodować zakłócenia logistyczne.

Tabela 2. Analiza zagrożenia wystąpienia awarii autobusu i oszacowanie ryzyka, jakie temu może towarzyszyć

\begin{tabular}{|l|l|l|c|c|c|}
\hline Lp. & \multicolumn{1}{|c|}{ Zagrożenie } & \multicolumn{1}{|c|}{ Obszar oddziaływania } & p & S & R \\
\hline 1. & $\begin{array}{l}\text { Awarie środków } \\
\text { transportu - autobusy }\end{array}$ & $\begin{array}{l}\text { Szlaki drogowe, miejsca odpoczynku } \\
\text { podróżnych itp. }\end{array}$ & 3 & 2 & $6^{21}$ \\
\hline
\end{tabular}

\subsubsection{Awarie środków transportu - pojazdy szynowe}

Planuje się, że kolej będzie wykorzystywana przede wszystkim do transportu grup polskich uczestników ${ }^{22}$ ŚDM z Podkarpacia. W tabeli 3 przedstawiono oszacowania parametrów i ryzyka dla pojazdów szynowych. Obserwacje dotyczące zdarzeń związanych $\mathrm{z}$ awariami pojazdów szynowych niebędących $\mathrm{w}$ ruchu są trudne do

\footnotetext{
${ }^{19}$ Wobec wielkiego zapotrzebowania na autobusy możliwe jest, że do ruchu będą kierowane samochody w nienajlepszym stanie technicznym. Dodatkowo, może się także zdarzyć, że niektórzy przewoźnicy wykorzystają okazję do podnoszenia cen za wynajem. Może to skutkować wybieraniem pojazdów tańszych, o gorszej jakości przez mniej zamożnych pielgrzymów.

${ }^{20}$ To zagrożenie nie determinuje katastrof w ruchu drogowym, które będą rozpatrywane przy zagrożeniu wypadkami komunikacyjnymi.

${ }^{21}$ Wartość oszacowania ryzyka wyliczana jest przez iloczyn prawdopodobieństwa i strat: $\mathrm{R}=\mathrm{p} * \mathrm{~S}=6$.

${ }^{22}$ Według informacji przekazanych przez diecezjalnych koordynatorów przygotowań ŚDM z poszczególnych diecezji obejmujących tereny województwa podkarpackiego.
} 
przeprowadzenia, ponieważ takie zepsute lokomotywy ani wagony nie podjeżdżają na peron po podróżnych. Można uogólnić tę praktykę i założyć, że będzie ona funkcjonować także w rozważanym okresie. Trzeba równieżuwzględnić poprawę jakości taboru wynikającą z trwającego od kilku lat procesu jego modernizacji i wymiany w oparciu na dostępnych w tym celu środkach z funduszy unijnych. Biorąc pod uwagę dotychczasowe doświadczenia, można założyć prawdopodobieństwo zepsucia się pojazdu szynowego na poziomie „małe” ( $\mathrm{p}=2)$ i szkód z tym związanych na poziomie ,średnie” $(\mathrm{S}=3)$.

Tabela 3. Analiza zagrożenia wystąpienia awarii pojazdu szynowego i oszacowanie ryzyka, jakie temu może towarzyszyć

\begin{tabular}{|l|l|l|l|c|c|}
\hline Lp. & \multicolumn{1}{|c|}{ Zagrożenie } & Obszar oddziaływania & p & S & R \\
\hline 2. & $\begin{array}{l}\text { Awarie środków } \\
\text { transportu - pociąg }\end{array}$ & Pasażerowie, szlaki kolejowe, stacje i dworce & 2 & 3 & 6 \\
\hline
\end{tabular}

\subsection{Wypadki komunikacyjne}

Zagrożenie dotyczące wypadków komunikacyjnych należy w analizowanym okresie rozpatrywać na tle specyficznych warunków, wynikających ze szczególnie dużego natężenia ruchu na drogach $\mathrm{i}$ autostradach oraz na szlakach kolejowych. Jest to, w pewnym sensie, zagrożenie dopełniające przestrzeń oszacowaną przy awariach środków transportu. Wypadki komunikacyjne w ruchu lądowym pojawiają się jako skutek nieprawidłowości towarzyszącej przemieszczaniu się pojazdu lub pojazdów na zaplanowanej trasie. Podobnie jak w odniesieniu do awarii środków transportu, zagadnienie wypadków komunikacyjnych rozpatrywane będzie w odniesieniu do osobnych rodzajów transportu: drogowego, kolejowego oraz lotniczego.

\subsubsection{Wypadki komunikacyjne $z$ udziałem autobusów}

$\mathrm{W}$ rozpatrywanych warunkach drogowych $\mathrm{w}$ zestawieniu $\mathrm{z}$ dużym udziałem wysłużonych autobusów należy założyć, że prawdopodobieństwo wypadku ${ }^{23} \mathrm{z}$ udziałem autobusu będzie na poziomie ,średni” $(p=3)$, zaś straty tym spowodowane, zwłaszcza możliwe przypadki śmiertelne wśród ofiar takiego wypadku, należy oszacować jako „zupełne” $(\mathrm{S}=5)$.

Tabela 4. Analiza zagrożenia wypadku komunikacyjnego z udziałem autobusu i oszacowanie ryzyka, jakie temu może towarzyszyć

\begin{tabular}{|l|l|l|l|c|c|}
\hline Lp. & \multicolumn{1}{|c|}{ Zagrożenie } & Obszar oddziaływania & p & S & R \\
\hline 3. & $\begin{array}{l}\text { Wypadki komunikacyjne } \\
\text {-autobusy }\end{array}$ & $\begin{array}{l}\text { Podróżni, osoby postronne, pojazdy, } \\
\text { infrastruktura drogowa i techniczna }\end{array}$ & 3 & 5 & 15 \\
\hline
\end{tabular}

\subsubsection{Wypadki komunikacyjne z udziałem pociągów}

Wypadek kolejowy to niezamierzone nagłe zdarzenie lub ciąg takich zdarzeń $\mathrm{z}$ udziałem pojazdu kolejowego, powodujące negatywne konsekwencje dla zdrowia

\footnotetext{
${ }^{23}$ Do celów statystycznych stosuje się definicję wypadku drogowego: ,zdarzenie mające związek z ruchem pojazdów na drogach publicznych, w wyniku którego nastąpiła śmierć lub uszkodzenie ciała osób. Za śmiertelną ofiarę wypadku drogowego uznaje się osobę zmarłą w wyniku doznanych obrażeń na miejscu lub w ciągu 30 dni. Za ranną ofiarę wypadku drogowego uznaje się osobę, która doznała obrażeń ciała i otrzymała pomoc lekarską". Por.

http://web.archive.org/web/20140202095138/http://www.stat.gov.pl/gus/definicje_PLK_HTML.htm?id=POJ3289.htm (dostęp: 29.01.2016).
} 
ludzkiego, mienia lub środowiska. Do wypadków zalicza się w szczególności: kolizje, wykolejenia, zdarzenia na przejazdach, zdarzenia z udziałem osób spowodowane przez pojazd kolejowy będący w ruchu, a także pożar pojazdu kolejowego ${ }^{24}$. Kolej polska nie ma najlepszej opinii na tle innych przewoźników w Unii Europejskiej. Wynika to z wielu lat zaniedbań i zaniechań. Niemniej jednak w ostatnich kilku latach za sprawą inwestycji na liniach kolejowych oraz zakupów taboru realizowanych przy wsparciu środków unijnych w ramach kończącej się perspektywy finansowej Unii Europejskiej 2007-2013 sytuacja znacznie się poprawiła. Wśród czynników powodujących wzrost zagrożenia wypadków w rozważanym okresie należy wskazać przede wszystkim zwiększenie liczby dodatkowych składów pasażerskich jadących po tych samych torach co składy „rozkładowe” i pociągi towarowe. W wyniku napiętego rozkładu jazdy, odmiennej organizacji przejazdów i miejsc postoju, zmęczenia i stresu wśród pracowników oraz dynamicznie zmieniającej się sytuacji trzeba założyć, że prawdopodobieństwo wystąpienia wypadków w transporcie kolejowym będzie na poziomie „małym” do „średniego” 25 lipca 2016 roku, kiedy nastąpi kulminacja przejazdów. Zewzględuna przyjęty etap rozważanej imprezy, autor przyjmuje do dalszych rozważań prawdopodobieństwo „małe” $(\mathrm{p}=2)$. Biorąc jednak pod uwagę wcześniej opisaną sytuację iuwzględniając także skłonność do aktów samobójczych w obliczu dziejących się wydarzeń, straty spowodowane przez takie wypadki szacuje się na poziomie „duże” ( $\mathrm{S}=$ 4) albo nawet ,zupełne” $(S=5)$. Dla przyjętych założeń $-S=5$.

Tabela 5. Analiza zagrożenia wypadkiem w ruchu kolejowym i oszacowanie ryzyka, jakie może temu towarzyszyć

\begin{tabular}{|l|l|l|c|c|c|}
\hline Lp. & \multicolumn{1}{|c|}{ Zagrożenie } & \multicolumn{1}{|c|}{ Obszar oddziaływania } & p & S & R \\
\hline 4. & $\begin{array}{l}\text { Wypadki komunikacyjne } \\
\text {-pociągi }\end{array}$ & $\begin{array}{l}\text { Podróżni, osoby postronne, pojazdy } \\
\text { kolejowe: lokomotywy i wagony, tor } \\
\text { kolejowe, infrastruktura techniczna }\end{array}$ & 2 & 5 & 10 \\
\hline
\end{tabular}

\subsubsection{Wypadki komunikacyjne w lotnictwie}

Transport lotniczy postrzegany jest jako najbardziej bezpieczny. Niemniej jednak kiedy już dochodzi do fatalnego zdarzenia z udziałem statku powietrznego, to zwykle jest ono wyjątkowo tragiczne. Wobec takiego obrazu zagadnienia należy przyjąć jedyny możliwy pakiet oszacowań: $\mathrm{p}=1, \mathrm{~S}=5$, a zatem $\mathrm{R}=5$.

Tabela 6. Analiza zagrożenia wypadkiem w ruchu kolejowym i oszacowanie ryzyka, jakie może temu towarzyszyć

\begin{tabular}{|l|l|l|l|l|l|}
\hline Lp. & \multicolumn{1}{|c|}{ Zagrożenie } & Obszar oddziaływania & p & S & R \\
\hline 5. & $\begin{array}{l}\text { Wypadki komunikacyjne } \\
\text {-samoloty }\end{array}$ & $\begin{array}{l}\text { Pasażerowie, samoloty, osoby postronne, } \\
\text { infrastruktura techniczna }\end{array}$ & 1 & 5 & 5 \\
\hline
\end{tabular}

\subsection{Problemy logistyczne w obsłudze transportów}

Stopień komplikacji zadań związanych z organizacją transportu uczestników ŚDM w 2016 r.sprawia, że w wielu wypadkach mogą się pojawić opóźnienia w przejazdach drogowych i kolejowych. To zagrożenie może się wiązać $\mathrm{z}$ bardzo prozaicznymi okolicznościami, na przykład z niezwykle napiętym rozkładem jazdy w dniach, kiedy

\footnotetext{
${ }^{24}$ Por. ustawa z dnia 28 marca 2003 r. o transporcie kolejowym (Dz.U. 2003 nr 86 poz. 789 ze zm.), art. 4 pkt 45.
} 
kumulować się będzie ruch w kierunku centralnych miejsc dla ŚDM. Z informacji uzyskanych w Wojewódzkim Centrum Zarządzania Kryzysowego wynika, że 25 lipca 2016 r. do Krakowa $\mathrm{z}$ terenu województwa podkarpackiego przyjedzie około 100 pociągów osobowych ${ }^{25}$ oraz blisko 300 autobusów $^{26}$. W odniesieniu do pociągów istotnym problemem mogą być wymuszone sytuacją nieprzewidziane postoje na trasie. Może się zdarzyć, zwłaszcza w okolicach Krakowa, że pasażerowie zatrzymanego przed semaforem pociągu uznają, że szybciej dotrą do celu pieszo, niż czekając, aż pociąg ruszy i dojedzie do dworca. To może powodować spore zakłócenia dla bieżącego ruchu kolejowego (ludzie przechodzący przez tory kolejowe w przypadkowych, niedozwolonych miejscach). Mając na względzie dostępność toalet i punktów żywieniowych wzdłuż autostrady A4 na odcinku od Rzeszowa do Krakowa, można się spodziewać długich kolejek. To może powodować poszukiwanie „wariantów alternatywnych", co spowoduje zagrożenie dla bezpieczeństwa podróżnych i zanieczyszczenie środowiska naturalnego wokół Miejsc Obsługi Podróżnych przy autostradzie. Niewiele lepiej wyglądać może sytuacja wzdłuż innych dróg dojazdu do Krakowa i Wieliczki. Oszacowanie parametrów i samego ryzyka dla tego zagrożenia przedstawiono w tabeli 7.

Tabela 7. Analiza zagrożenia problemami logistycznymi w transporcie i oszacowanie ryzyka, jakie może temu towarzyszyć

\begin{tabular}{|l|l|l|c|c|c|}
\hline Lp. & \multicolumn{1}{|c|}{ Zagrożenie } & \multicolumn{1}{|c|}{ Obszar oddziaływania } & p & S & R \\
\hline 6. & $\begin{array}{l}\text { Problemy logistyczne w } \\
\text { obsłudze transportów }\end{array}$ & $\begin{array}{l}\text { Pasażerowie, parkingi, lokale } \\
\text { gastronomiczne, toalety, dworce, otoczenie, } \\
\text { osoby postronne }\end{array}$ & 4 & 2 & 8 \\
\hline
\end{tabular}

\subsection{Przerwy w dostawach energii do kolejowej trakcji elektrycznej}

Dokuczliwość niedoboru energii elektrycznej zależy od rozpatrywanego miejsca pobytu uczestników ŚDM. W wypadku braku zasilania na określonym odcinku linii kolejowej, po której poruszają się pociągi elektryczne i ciągnięte przez elektrowozy składy osobowe, pojawi się nieprzejezdny zator ${ }^{27}$, który może spowodować bardzo duże komplikacje logistyczne zarówno w obszarze transportu podróżnych, jak i w obszarze ich zakwaterowania i wyżywienia.Zakładając, że przerwy, jeśli się zdarzą, będą miały wymiar nie dłuższy niż kilka godzin, oszacowania parametrów można przyjąć następująco: $\mathrm{p}=3$, $\mathrm{S}=2, \mathrm{R}=6$.

Tabela 8. Analiza zagrożenia przerw w dostawie energii elektrycznej i oszacowanie ryzyka, jakie może temu towarzyszyć

\begin{tabular}{|l|l|l|c|c|c|}
\hline Lp. & \multicolumn{1}{|c|}{ Zagrożenie } & \multicolumn{1}{|c|}{ Obszar oddziaływania } & P & R \\
\hline 7. & $\begin{array}{l}\text { Przerwy w dostawach } \\
\text { energii elektrycznej }\end{array}$ & $\begin{array}{l}\text { Obiekty mieszkalne, wyposażenie imprez } \\
\text { masowych }\end{array}$ & 3 & 2 & 6 \\
\hline
\end{tabular}

\footnotetext{
${ }^{25}$ Przyjmując, że średnio w takim składzie podróżuje około 700 osób, oznacza to, że do Krakowa na ŚDM i spotkanie z papieżem koleją wybierze się około 70 tysięcy pielgrzymów z Podkarpacia.

${ }^{26}$ Według oszacowań liczba zagranicznych uczestników ŚDM, którzy dni diecezjalne spędzą w województwie podkarpackim, może wynieść około 12 tys. osób. Zakładając, że średnio do autobusu może wsiąść 40 osób, to daje liczbę około 300 pojazdów.

${ }^{27}$ Wyprzedzanie na szlaku kolejowym jest znacznie bardziej skomplikowane niż w wypadku ruchu drogowego. Nawet jeśli do dyspozycji jest kilkutorowa linia kolejowa, to rozpoczęcie i zakończenie manewru możliwe jest tylko w specjalnie do tego przygotowanych miejscach -kolejowych węzłach ze zwrotnicami.
} 


\subsection{Terroryzm}

Rok 2015 zaznaczył się w historii Europy wyjątkowym nasileniem terroryzmu. Dotyczy to w szczególności zamachów o podłożu religijnym. Rozważając zjawisko terroryzmu w odniesieniu do ŚDM,trzeba mieć na względzie to, że Polska należy do strefy Schengen ${ }^{28}$, co oznacza, że analiza wymaga uwzględnienia sytuacji we wszystkich krajach z tego obszaru. W ostatnich miesiącach kraje „starej Unii” stały się celem ataków terrorystycznych dokonywanych najczęściej przez bojowników „państwa islamskiego"29. Charakterystyczne dla przywołanych aktów terroru było to, że zamachowcami byli młodzi ludzie - obywatele krajów europejskich, a logistyka przygotowań do zamachów oparta była namiejscach i lokalach znajdujących się w tych samych lub nieodległych europejskich państwach. Konieczna jest świadomość, że podobne scenariusze mogą zostać użyte do przygotowania i przeprowadzenia zamachów w Polsce. Wprawdzie na ulicach polskich miast osoba innego koloru skóry i odmiennej kultury jest widoczna wyraźniej niż na przykład we Francji, to przyjazdy na Światowe Dni Młodzieży mogą istotnie zaburzyć tęprawidłowość. Dużo będzie młodych ludzi z torbami i plecakami, wśród których łatwo może się ukryć osoba o złych zamiarach ${ }^{30}$. Zebranie w jednym czasie i miejscu bardzo licznych grup ludzi, udział Ojca Świętego i wielu innych ważnych osobistości świata polityki, dyplomacji, sportu i sztuki, ustawiczny przekaz medialny ${ }^{31}$, ułatwienia dla podróżujących, wszystko to są czynniki, które stwarzają wręcz idealne warunki dla zamachowców. Biorąc topod uwagę, można założyć, że największe zagrożenie terrorystyczne będzie dotyczyć imprez organizowanych w Krakowie i okolicach. Niemniej jednak trzeba mieć na uwadze, że dla efektu wystarczy zadać cios w najsłabsze miejsce, które wprost kojarzyć się będzie ze ŚDM. Oznacza to, że nie można wykluczyć terrorystycznej agresji kierowanej w stronę nawet najmniejszych grup uczestników ŚDM w diecezjach. Ranga imprezy i wszystko inne, które zostało tu wymienione, sprawia, że nad zabezpieczeniem ŚDM pracuje grono specjalistów z kraju, Europy i ze świata. Ze względu na charakter prowadzonych działań nie sposób jednoznacznie ich tu opisać. Uwzględniając to,autor założył następujące oszacowania czynników ryzyka: prawdopodobieństwo „małe”, straty zaś „,zupełne”.

Tabela 9. Analiza zagrożenia terrorystycznego i oszacowanie ryzyka, jakie może temu towarzyszyć

\begin{tabular}{|l|l|l|l|l|c|}
\hline Lp. & \multicolumn{1}{|c|}{ Zagrożenie } & \multicolumn{1}{|c|}{ Obszar oddziaływania } & p & S & R \\
\hline 8. & Terroryzm & $\begin{array}{l}\text { Uczestnicy, służby, politycy, media, } \\
\text { publiczność }\end{array}$ & 2 & 5 & 10 \\
\hline
\end{tabular}

\footnotetext{
${ }^{28}$ Zob. Podstawowe informacje o strefie Schengen na stronie: https://www.mswia.gov.pl/pl/wspolpracamiedzynarod/unia-europejska/schengen/7094,dok.html (dostęp: 30.01.2016).

${ }^{29}$ ISIS - akronim pochodzi od angielskich słów IslamicState of Iraq and Sham i oznacza salaficką organizację terrorystyczną, która od 29 czerwca 2014 r. podaje się za państwo islamskie. Często spotyka się skracanie nazwy także do IS, ISIL. Oficjalnym celem ugrupowania jest utworzenie islamskiego państwa opartego na zasadach szariatu regulującego zwyczaje nie tylko religijne, ale też organizację władzy religijnej oraz codzienne życie każdego muzułmanina. Opracowanie własne autora na podstawie: http://www.nowastrategia.org.pl/ znaczenie-flagi-panstwa-islamskiego-isis/ (dostęp: 10.02.2016).

${ }^{30} \mathrm{~W}$ taki sposób zamachowcy poruszali się wśród kibiców dopingujących uczestników maratonu w Bostonie. Na podstawie: http://www.polskieradio.pl/5/3/Artykul/827339,Oblawa-w-Bostonie-Torba-widzialem-facetaspojrzal-na-mnie (dostęp: 30.01.2016).

${ }^{31}$ Jednym z celów działań terrorystycznych jest uzyskanie rozgłosu. Dzięki mediom terroryści osiągają dodatkowe cele polegające między innymi na zaszczepieniu wśród obserwującej przekaz publiczności poczucia niepewności, strachu i niewiary w sprawność i skuteczność służb działających dla ich bezpieczeństwa.
} 


\section{OCENA RYZYKA}

Wyniki analizy zagrożeń stanowią dane do procesu zarządzania ryzykiem. Użyto do tego metodę matrycową $\mathrm{z}$ zastosowaniem matrycy strategicznej uwzględniającej następujące warunki ${ }^{32}$ :

1. Ryzyko nieakceptowane - skwantyfikowana wartość oszacowanego ryzyka przekracza założoną wartość progową (może to także dotyczyć każdego ze składników ryzyka: prawdopodobieństwa $\mathrm{i}$ strat). Zarządzanie takim ryzykiem wymaga podjęcia zdecydowanych kroków mających na celu jego wyeliminowanie (unikanie ryzyka), zminimalizowanie (redukcja ryzyka) albo jego przeniesienie na inny podmiot (transfer ryzyka). Należy podjąć natychmiastowe działania w celu zwiększenia bezpieczeństwa, zmienić stosowane rozwiązania i procedury.

2. Ryzyko warunkowo akceptowalne - wartość ryzyka mieści się w obustronnie zakreślonym przedziale, w którym dopuszcza się funkcjonowanie obiektu na zasadach uwzględniających określone ograniczenia i zastrzeżenia (może to dotyczyć także poszczególnych czynników ryzyka: p i S). Należy na czas trwania imprezy wprowadzić dodatkowe środki bezpieczeństwa lub poprawić już stosowane rozwiązania.

3. Ryzyko akceptowalne to taka wartość ryzyka materializacji zagrożenia, która uzasadnia pozostawienie sytuacji $\mathrm{w}$ analizowanym obiekcie (obszarze) bez potrzeby dodatkowych działań albo tylko niewielkich działań. Taki poziom ryzyka oznacza, że zmaterializowanie się tego konkretnego zagrożenia jest albo praktycznie niemożliwe, albo straty z tym związane są pomijalnie małe. Nie są wymagane żadne dodatkowe środki bezpieczeństwa, akceptowane są aktualne rozwiązania i przypisane im siły i środki, działania monitorujące.

4. Matryca strategiczna:

a. wszystkie ryzyka, dla których straty zostały oszacowane jako „zupełne” oraz prawdopodobieństwo jest większe od minimalnego, są nieakceptowalne;

b. na pozostałym obszarze matrycy ryzyko szacowane jest metodą iloczynową;

c. ryzyka większe lub równe 15 są nieakceptowalne;

d. ryzyka należące do przedziału większe lub równe 5 i mniejsze niż15 będą traktowane jako warunkowo akceptowalne;

e. ryzyka mniejsze niż 5 będą traktowane jako akceptowalne.

W tabeli 10 zawarto wszystkie skatalogowane w niniejszym opracowaniu ryzyka dla działań komunikacyjnych i na jej podstawie sporządzono strategiczną matrycę ryzyka.

Tabela 10. Analiza zagrożeń i szacowanie związanych z nimi ryzyk

\begin{tabular}{|l|l|l|c|c|c|}
\hline Lp. & \multicolumn{1}{|c|}{ Zagrożenie } & \multicolumn{1}{|c|}{ Obszar oddziaływania } & P & R \\
\hline 1. & $\begin{array}{l}\text { Awarie środków } \\
\text { transportu -autobusy }\end{array}$ & $\begin{array}{l}\text { Szlaki drogowe, miejsca odpoczynku } \\
\text { podróżnych itp. }\end{array}$ & 3 & 2 \\
\hline 2. & $\begin{array}{l}\text { Awarie środków } \\
\text { transportu -pociągi }\end{array}$ & Pasażerowie, szlaki kolejowe, stacje i dworce & 2 & 3 & 6 \\
\hline 3. & $\begin{array}{l}\text { Wypadki komunikacyjne } \\
\text { - autobusy }\end{array}$ & $\begin{array}{l}\text { Podróżni, osoby postronne, pojazdy, } \\
\text { infrastruktura drogowa i techniczna }\end{array}$ & 3 & 5 & 15 \\
\hline 4. & $\begin{array}{l}\text { Wypadki komunikacyjne } \\
\text {-pociągi }\end{array}$ & $\begin{array}{l}\text { Podróżni, osoby postronne, kolejowe } \\
\text { pojazdy: lokomotywy i wagony, tory } \\
\text { kolejowe, infrastruktura techniczna }\end{array}$ & 2 & 5 & 10 \\
\hline
\end{tabular}

\footnotetext{
${ }^{32}$ Opracowanie własne autora.
} 


\begin{tabular}{|l|l|l|c|c|c|}
\hline 5. & $\begin{array}{l}\text { Wypadki komunikacyjne } \\
\text {-samoloty }\end{array}$ & $\begin{array}{l}\text { Pasażerowie, samoloty, osoby postronne, } \\
\text { infrastruktura techniczna }\end{array}$ & 1 & 5 & 5 \\
\hline 6. & $\begin{array}{l}\text { Problemy logistyczne w } \\
\text { obsłudze transportów }\end{array}$ & $\begin{array}{l}\text { Pasażerowie, parkingi, lokale } \\
\text { gastronomiczne, toalety, dworce, otoczenie, } \\
\text { osoby postronne }\end{array}$ & 4 & 2 & 8 \\
\hline 7. & $\begin{array}{l}\text { Przerwy w dostawach } \\
\text { energii elektrycznej }\end{array}$ & $\begin{array}{l}\text { Obiekty mieszkalne, wyposażenie imprez } \\
\text { masowych }\end{array}$ & 3 & 2 & 6 \\
\hline 8. & Terroryzm & $\begin{array}{l}\text { Uczestnicy, służby, politycy, media, } \\
\text { publiczność }\end{array}$ & 2 & 5 & 10 \\
\hline
\end{tabular}

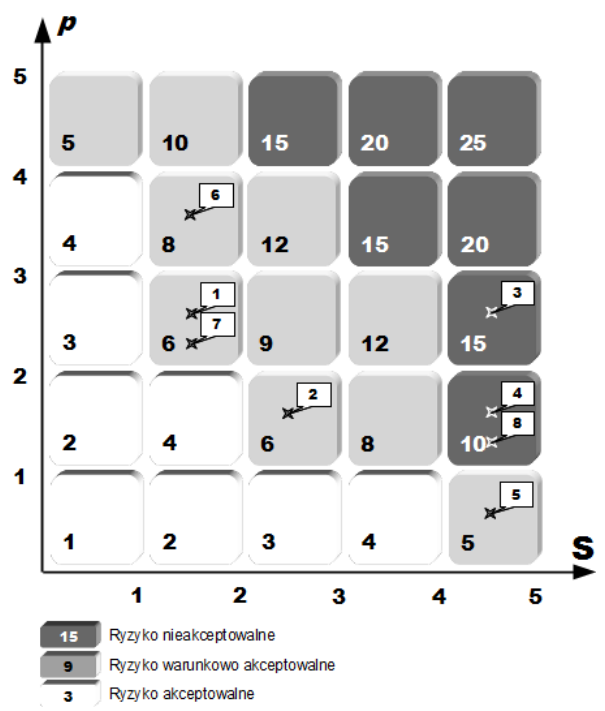

Rys.2. Mapa ryzyka - matryca strategiczna ryzyka materializacji zagrożeń związanych ze zbiorowym transportem uczestników Światowych Dni Młodzieży

Na rysunku 2 przedstawiono mapę ryzyka dla zagrożeń związanych z transportem zbiorowym uczestników ŚDM w formie matrycy strategicznej opracowanej według wcześniej poczynionych założeń. Ocena ryzyka pokazuje, że wśród nieakceptowalnych znalazły się następujące zdarzenia:

- wypadki komunikacyjne z udziałem autobusów (nr 3);

- wypadki komunikacyjne z udziałem pociągów (nr 4);

- terroryzm (nr 8).

Warunkową akceptację ryzyka dopuszcza się dla:

- awarii autobusów (nr 1);

- awarii pociągów (nr 2);

- wypadków komunikacyjnych z udziałem samolotów (nr 5);

- problemów logistycznych w obsłudze transportu (nr 6);

- przerw w dostawach energii elektrycznej w trakcji kolejowej (nr 7).

Wśród zagrożeń związanych z działaniami transportowymi realizowanymi na potrzeby przemieszczania uczestników ŚDMw diecezjach nie ma żadnego, dla którego ryzyko byłoby akceptowalne. 


\section{PODSUMOWANIE}

Przeprowadzone przez autora analizy zagrożeń i oszacowania czynników ryzyka pokazały w zakresie komunikacji zbiorowej, że zapewnienie bezpieczeństwa ŚDM wymaga zdecydowanych działań w związku z możliwymi wypadkami w ruchu kołowym oraz kolejowym. Należy pamiętać, że analizowane parametry mają charakter statyczny i są związane z okresem początku roku 2016. Rzeczywisty obraz zagrożeń i ryzyk ich materializacji w czasie ŚDMmoże, ze względu na dynamicznie zmienne czynniki, istotnie od nich odbiegać. Niemniej jednak analiza pokazała, że potrzeba dodatkowych działań w odniesieniu do możliwych awarii środków transportu, zapewnieniu sprawności działań przy wsiadaniu i wysiadaniu podróżnych, a także $\mathrm{w}$ związku $\mathrm{z}$ zapewnieniem nieprzerwanych dostaw energii elektrycznej do trakcji zasilającej elektrowozy ciągnące pociągi. Założenie, że w komunikacji lotniczej zagrożenie wypadkiem można oszacować jako warunkowo akceptowalne, bierze się z wdrożenia na lotniskach i w samolotach procedur, które mają na celu wyeliminowanie możliwości materializacji tego zagrożenia. Osobnym, niepoddanym analizie obszarem, są drony. Te bezzałogowe zdalnie sterowane statki powietrzne coraz częściej pojawiają się $\mathrm{w}$ przestrzeni powietrznej i niestety, nie zawsze jest to działanie w pełni profesjonalne, odpowiedzialne i bezpieczne. Szczególnej staranności wymaga właściwe przygotowanie zabezpieczenia transportu przed możliwymi atakami terrorystycznymi.

\section{LITERATURA}

[1] Ulman P., Polska rodzina $w$ świetle wybranych badań statystycznych, „Studia SocialiaCracoviensia"10/6 (2014) .

[2] Ustawa z 26 kwietnia 2017 r. o zarządzaniu kryzysowym (Dz.U. 2007 nr 89, poz. 590 ze zm.).

[3] Ustawa z dnia 20 marca 2009 r. o bezpieczeństwie imprez masowych (Dz.U. $2009 \mathrm{nr} 62$ poz. 504 ze zm.).

[4] Ustawa z dnia 28 marca 2003 r. o transporcie kolejowym (Dz.U. 2003 nr 86 poz. $789 \mathrm{ze} \mathrm{zm}$.).

[5] Ustawa z dnia 3 lipca 2002 r. Prawo lotnicze (Dz.U. 2002 nr 130 poz. 1112 ze $\mathrm{zm}$.).

[6] Ustawa z dnia 6 września 2001 r. o transporcie drogowym (Dz.U. 2001 nr 125 poz. 1371 ze zm.).

[7] Podstawowe informacje o strefie Schengen, https://www.mswia.gov.pl/pl/ wspolpraca-miedzynarod/unia-europejska/schengen/7094,dok.html.

[8] Threat and Risk Assessment Working Guide, http://www.iwar.org.uk/comsec/ resources/risks/itsg-04e.pdf.

[9] http://www.pogodynka.pl/polska/daneklimatyczne/.

[10] http://web.archive.org/web/20140202095138/http://www.stat.gov.pl/gus/ definicje_PLK_HTML.htm?id=POJ-3289.

[11] http://www.polskieradio.pl/5/3/Artykul/827339, Oblawa-w-Bostonie-Torbawidzialem-faceta-spojrzal-na-mnie. 


\section{WORLD YOUTH DAY 2016 -HAZARD ANALYSIS AND EVALUATION OF RISKS OF TRANSPORTATION. STUDY ON THE EXAMPLE OF DAYS IN DIOCESES IN PODKARPACKIE REGION}

World Youth Day is time when young people, Catholics and not only, from all over the world come to meet the Holy Father and other people like them. They spend their time in pray, vigils, discussions and getting to know new places for them. It is undoubtedly an opportunity to live a unique adventure in close proximity to people who look at the world in the same way and likewise perceiving its values. Due to the size of the event and the scale of actions that must be taken to its proper conduct, it is necessary to thoroughly analyse the safety issues. The occasion in itself is neither a crisis nor a mass event at increased risk. However, especially in view of the terrorist attacks carried out in the countries of so-called „old Europe" there are needed analyses and based on their results operational activities to prepare safety for all participants on all meeting places and around them. The program of WYD involves two parts. First stage, the diocesan days, scheduled from 20 to 25 of July 2016 will be held in parishes scattered around the country where guests from the whole world will take part in the programs prepared by local communities. And the second part, the main stage of the event will start 25th and take time to 31th of July in Krakow. For pilgrims it will be a time to meet the Holy Father and for common pray with him. One needs to expect that entire population of participants would want to get to Krakow and surrounding area then. That means that city less than 800 thousand inhabitants will host crowds of pilgrims estimated even at 3 million people.

Keywords: WYD, transportation, threat, risk.

DOI:10.7862/rz.2015.hss.53

Przesłano do redakcji: październik 2015

Przyjęto do druku: grudzień 2015 